\title{
Effect of Organic Fertilizers on Nutrients Content and Essential Oil Composition of Savory (Satureja hortensis L.)
}

\author{
Behrooz Esmaielpour ${ }^{1 *}$, Mahdi rahmanian' ${ }^{1}$, Surur khorramdel ${ }^{2}$, Hojjat Gharavi ${ }^{2}$ \\ ${ }^{1}$ College of Agriculture and Natural Resources, University of Mohaghegh Ardabili, Iran \\ ${ }^{2}$ College of Agriculture, Ferdowsi University of Mashhad, Iran \\ *Email: behsmaiel@yahoo.com
}

Submission: September 16, 2017; Acceptance: October 29, 2018

\begin{abstract}
Application of organic fertilizers in the production of plants is aimed to eliminate or substantially reduce the use of chemical inputs and improve the growth and quality of plants. For instance, in present study, the effect of vermicompost and spent mushroom compost application on nutritional status and essential oil components of summer Savory (Saturejahortensis L.) was investigated. This experiment was conducted in the research greenhouse of Faculty of Agriculture at Mohaghegh Ardabili University using a layout of completely randomized design with five replications on Savory in 2014. Experimental treatments included different substrates that contained vermicompost, washed and unwashed spent mushroom compost in five levels $(10,20,30,40$ and 50 Percent $\mathrm{v} / \mathrm{v}$ ). After flowering, the plants were harvested and parameters such as leaf area, leaf and plant dry weight, chlorophyll index of leaf and N, P, K, and Ca content and essential oil component of plants were measured. The results showed that the effect of organic substrates on macronutrient content and savory's growth parameters was significant. The highest Nitrogen content (6.3\%) and Phosphorus $(0.98 \%)$ in savory shoot was obtained in a substrate supplemented with $40 \%$ vermicompost. Plants grown in the media containing $30 \%$ of vermicompost and $50 \%$ of washed spent mushroom compost (SMC) have higher potassium $(3.19 \%)$ and calcium $(2.48 \%)$ content, respectively. The lowest nitrogen, phosphorus and potassium content in the aerial part was obtained in the control treatment. Moreover, application of organic fertilizers significantly affected on savory's essential oil percentage and compounds composition. The highest and lowest essential oil contents were obtained in plants in substrates containing $30 \%$ of vermicompost and unwashed spent mushroom compost respectively. The main components of essential oil were carvacrol and gamma-trepenine. The highest level of carvacrol (62.10) and gamma-trepenine (32.05) were obtained in plants in substrates containing 40 and $20 \%$ of washed spent mushroom respectively.
\end{abstract}

Keywords: Essential oil; leaf area index, nutrients, savory, vermicompost

\section{INTRODUCTION}

Summer savory (Satureja hortensis L.) is an annual and herbaceous plant belonging to the Lamiaceae family. This herb is native to Mediterranean region (Hadian et al., 2008) with small flowers $(1.5 \mathrm{~mm})$ and long leaves. The leaves contain essential oil and compounds (Omidbeigi, 2000) such as phenols, carvacrol, thymol, beta caryophyllene, linalool and terpenoids (Omidbaigi and Hejazi, 2004). Savory is widely used in culinary applications and as an herbal medicine to boost sexual potency and to treat paroxysm and bloating (Hadian et al., 2008; Hidalgo et al., 2002).Today, economic and environmental impacts due to extensive use of chemical fertilizers are becoming globally threatening so an appropriate alternative for this type of fertilizers should be substituted (Gholami Sharafkhane et al., 2015).

A global approach in medicinal plants production is to establish a sustainable system and to apply management practices. Composts are among the most common organic fertilizers used in sustainable agricultural systems (Kiani et al., 2014; Nooshkam et 
al., 2015; Sharma, 2002). About 38 billion cubic meters of organic material are produced annually by humans, animals and plants around the world. This volume of waste can be recycled to a variety of agricultural fertilizers, including compost and vermicomost, (Asghari et al., 2012; Sharma, 2002).

Vermicompost is one of the organic fertilizers, produced as a result of earthworms' activity on organic materials. Vermicompost has high porosity, nutrients retention capacity, ventilation and drainage, microbial activity and water storage capacity (Sangwan et al., 2008). In addition, vermicompost is rich in vitamins, enzymes beneficial microorganisms and plant growth regulators such as auxins, gibberellins and cytokinins (Hidalgo et al., 2002; Frankenberger et al., 1995; Locanzo et al., 2009; Singh et al., 2003; Atiyeh et al., 2000; Arancon et al., 2007). Furthermore, vermicompost increases nitrogen and phosphorus availability for plants (Pradha et al., 2007; Tiwari et al., 1989).

Spent mushroom compost (SMC) is another type of organic fertilizers which can be used as soil amendment. SMC is rich in micro and macro nutrients and is used as for improving soil structure, ventilation and microbial activity (Betnal et al., 1998; Arthur et al., 2012; Courtney et al., 2008; Gonani et al., 2011; Ratti et al., 2001). Although the importance of SMC is well established in the world, the literature on its application in Iran is scanty so that SMC is still considered as waste material (Philippoussis et al., 2004). (Peregrina et al., 2009) showed that SMC application not only increases soil organic matter and nitrogen content, buts also improves soil structure (Peregrina et al., 2009).

In a study, application of cattle manure, vermicompost and biologic fertilizers including nitroxin, bio-sulfur, bio-phosphorus and combination of them could increase growth indexes and essences content compared with control treatment (Gholami Sharafkhane et al., 2015). In addition, increase in plant height, branches number, flower dry weight, shoot dry weight and essence percentage have been reported in savory treated with chemical and bio-fertilizers (Makkizadeh Tafti et al., 2012) Moreover, (Hossaini et al., 2015) have reported that the maximum essence percentage in savory plants (Satureja sahandica) was obtained when 2 ton ha-1 vermicompost was applied (Hossaini et al., 2015). Positive effects of biological and organic fertilizers on savory and essential oil content have been documented by several authors (Naeeji et al., 2015; Rezvani-Moghadam et al., 2013).

In a similar study on dragonhead (Dracocephalum moldavica), (Mafakheri et al., 2012) have shown that vermicompost, azotobacter and bio-phosphate application increased morphophysiological attributes and essence content (Mafakheri et al., 2012). Vermicompost application could also increase vegetative growth and essence content in basil (Anwar et al., 2005). Given the importance and role of medicinal plants in human life, it is important to increase their production without the use of chemical inputs (Mafakheri et al., 2012). Hence, the current study was aimed to evaluate the effects of different vermicompost and SMC amounts on growth, nutrients content and essential oil composition of summer savory and to offer an alternative method to produce chemical free or organic products in a low input system.

\section{MATERIAL AND METHODS}

The current study was carried out as a pot experiment under greenhouse conditions based on a completely randomized design with five replicates at Mohaghegh Ardabili University in 2014. The day/night temperature was set on $25 / 20 \pm 2$ and relative humidity was $50-60 \%$. The experimental treatments consisted of 16 treatments: $10,20,3,40$ and $50 \%$ v/v vermicompost, $10,20,3,40$ and $50 \% \mathrm{v} / \mathrm{v}$ washed SMC and 10, 20, 3, 40 and $50 \% \mathrm{v} / \mathrm{v}$ unwashed SMC and one control. There were two pots for each replicate and four plants in each pot. Soil, vermicompost and SMC physicochemical are given in (Table 1).

SMC was washed to reduce salinity. Growth media consisted of three parts soil and one part sand. Different ratio of vermicompost and SMC were determined and mixed into growth media. Savory seeds ( 34 seeds) were sown in small plastic pots in May. After 4 weeks seedlings were transplanted into the main pots $(30 \times 35$ $\times 25)$. Irrigation was performed every two days ( 1 liter)

Table 1. Physicochemical properties of organic fertilizers and soil before starting of experiment

\begin{tabular}{ccccc}
\hline Soil & Vermicompost & $\begin{array}{c}\text { Unwashed } \\
\text { SMC }\end{array}$ & Washed SMC & Properties \\
\hline 0.068 & 35 & 79 & 42 & $(\%) \mathrm{OC}$ \\
0.014 & 3.51 & 0.378 & 0.25 & $(\%) \mathrm{N}$ \\
0.08 & 1.15 & 1.58 & 1.1 & $(\%) \mathrm{P}$ \\
0.03 & 1.25 & 1.53 & 1.18 & $(\%) \mathrm{K}$ \\
11.48 & 550 & 598 & 510 & $\left(\mathrm{mg} . \mathrm{kg}^{-1}\right) \mathrm{Fe}$ \\
10 & 300 & 320 & 290 & $\left(\mathrm{mg}^{-1} \mathrm{~kg}^{-1}\right) \mathrm{Mn}$ \\
3.5 & 250 & 380 & 285 & $\left(\mathrm{mg}^{-1} \mathrm{~kg}^{-1}\right) \mathrm{Zn}$ \\
0.82 & 45 & 52 & 42 & $\left(\mathrm{mg}^{-1} \mathrm{~kg}^{-1}\right) \mathrm{Cu}$ \\
7.1 & 7 & 7.68 & 7.1 & $\mathrm{pH}$ \\
1.2 & 1.1 & 12.88 & 5.6 & $\left(\mathrm{dS}^{-1} \mathrm{~m}^{-1}\right) \mathrm{EC}$ \\
\hline
\end{tabular}


to well establishment of the seedlings. The seedlings were transplanted into the main pots at $3-4$ true leaf stage. Then irrigation was performed every four days. Chlorophyll index was recorded from 9 leaves across the plants using SPAD-502 (Konica Minolta, Japan). Leaf and plant dry weights were determined for each pot separately. Leaf area was measured on four plants using Leaf Area Meter ( $\Delta T$, UK). Leave samples were taken and dried in an oven at $70{ }^{\circ} \mathrm{C}$ for 48 to determine nutrients content. Dried samples were grounded and digested using sulfuric acid, salicylic acid, oxygen peroxide and selenium method. Above ground nitrogen content was determined using Kjeldahl method (Emami et al., 2004). Phosphorus content was determined using spectrophotometer method. Potassium and calcium content were determined using flame photometer and titration methods, respectively (Emami et al., 2004).

In order to extract the essential oil four months after sowing leaf samples were collected from upper parts of the plants and dried at room temperature and sunlight protected area until $10-14 \%$ moisture content. Essence was extracted using water distillation method using Clevenger apparatus. Extracted oil was dried with sodium sulfate and then weighted. The samples were kept in dark and cool place until further analysis. Gas chromatography (Varian CP 3800) equipped with DB 1 column ( $25 \mathrm{~m}, 0.25 \mathrm{~mm}$ and $0.25 \mu \mathrm{m}$ ) was used to analyses the essence composition. The data were analyzed using SAS 9.1. The Duncan's multiple range test was used to compare the means.

\section{RESULTS AND DISCUSSION}

\section{Chlorophyll, Leaf Dry weight, Plant Dry Weight and Leaf Area}

Analysis of variance indicated that the effect of vermicompost and SMC (washed and unwashed) were significant on chlorophyll, leaf dry weight, plant dry weight and leaf area (Table 2). The results indicated that chlorophyll content increased in plants treated with organic fertilizers compared with control treatment. However, there was no significant difference between $10 \%$ unwashed SMC ad control treatment. The maximum chlorophyll (54.78 units) was related to $10 \%$ vermicompost treatment. By contrast the minimum chlorophyll (27.34 units) was found in control treatment (Table 3). Comparison of means showed that application of vermicompost and SMC (except for 30\% vermicompost and $50 \%$ SMC treatments) could increase leaf dry weight compared with control treatment.The maximum leaf dry weight ( $9.7 \mathrm{~g}$ per plant) was observed when $10 \%$ vermicompost was applied.
On the other hand, the minimum leaf dry weights were found when $30 \%$ vermicompost ( $2.24 \mathrm{~g}$ per plant) or $50 \%$ washed SMC ( $2.4 \mathrm{~g}$ per plant) were used (Table 3). According to (Table 3), vermicompost and SMC application (except for 30\%vermicomoist and 50\% washed SMC) could increase plant dry weight compared with control treatment. In addition, the results showed that the maximum plant dry weight (13.31 g per plant) was related to $10 \%$ vermicompost treatment. By contrast, the minimum values were obtained from $30 \%$ vermicomost ( $4.50 \mathrm{~g}$ per plant) and $50 \%$ washed SMC (5.09 g per plant) treatments (Table 3). Moreover, comparison of means indicated that 20 and $40 \%$ vermicompost treatments produced the maximum leaf area (38.0 and $38.36 \mathrm{~cm}^{2}$, respectively) whereas the control treatment showed the minimum leaf area ( 25.62 $\mathrm{cm}^{2}$ ) (Table 3). Vermicompost is rich in micro and macro nutrients as well as humic acid (Joshi et al., 2015). It seems that organic fertilizers improve plant growth and biomass production through increasing nutrients availability (Yousefi et al., 2015).

On the other hand, organic fertilizers help plants to better grow by improving soil physical properties, biological activity and water retention capacity (Naiji et al., 2015). In addition, vermicompost contains hormonal compounds which help plants produce more biomass and build strong roots and fight diseases (Bachman and Metzger, 2007). Increase in leaf area has been reported by (Mcginnis et al., 2003) who applied vermicompost on basil plants and stated that vermicompost improves soil physical properties, microorganisms' activity and soil water retention capacity (Mcginnis et al., 2003). Considering this fact that zinc plays a key role in synthesis of indole acetic acid and vermicompost is rich in this element (Table 1), increase in plant growth and dry matter production on account of vermicompost application is not surprising (Adinarayana and Kumar, 2006).

Increase in dry matter due to vermicompost application has been previously reported by (Muscolo et al., 1999). In addition, (Naiji and Souri, 2015) have reported that the maximum plant height, leaf area, leaf number, stem diameter and fresh and dry weight in savory were obtained when $20 \%$ vermicompost was applied (Naiji and Souri, 2015). In a study, in order to study the effects of organic and chemical fertilizers on growth and yield of savory, the maximum biological yield was obtained when vermicompost was used whereas the maximum plant height, branch number and biomass was obtained when phosphate soluble treatment was applied (Rezvani Moghaddam et al., 2013). Increase in plant height and branch number in savory on account of 7 ton ha-1 ${ }^{-1}$ vermicompost has been reported by (Gholami- 
Sharafkhane et al., 2015). Similarly, increase in growth paramters in (Satureja sahandica) (Hossaini et al., 2015), basil (Rezaee Moadab and Nabavi Klat, 2012; Rezaeifar, and Alizadeh Oskuie, 2015), dragonhead (Darzi and Haj Seyed Hadi 2015; Mafakheri et al., 2012) and Dracocephalum (Abbaszadeh and Zakerian, 2016; Neamati et al., 2014), have been reported. Our results are in agreement with these findings. According to other results in this research, correlation between chlorophyll index (SPAD) and dry matter weight was positive and significant (Table 6). Also, the correlation between leaf area and dry weight was positive and significant (Table 6). In addition, the correlation of nitrogen with leaf erea was positive and significant (Table 6). It seems that nitrogen supply, through increased leaf area, increases plant dry weight and the increase of chlorophyll content, can be effective in increasing the plant dry matter by increasing the photosynthetic capacity of the plant.

\section{Nitrogen, Phosphorus, Potassium and Calcium Concentration}

The analysis of variance indicated that the effect of organic fertilizers was significant on nitrogen, phosphorus, potassium and calcium concentration in above ground parts of savory plants (Table 2). In addition, comparison of means revealed that organic fertilizers could increase nutrients content in above ground parts of savory compared with control treatment

Table 2. Analysis of variance of the effects of different level of vermicompost and spent mushroom compost on vegetative growth characteristic and macro elements content of summer savory foliage

\begin{tabular}{|c|c|c|c|c|c|c|c|c|c|}
\hline \multirow{2}{*}{$\begin{array}{l}\text { Source of } \\
\text { Variation }\end{array}$} & \multicolumn{8}{|c|}{ Means of squares } & \multirow{2}{*}{ df } \\
\hline & Calcium & Potassium & phosphorus & Nitrogen & Leaf area & Leaf dry weight & Plant dry weight & Greening index of leaf & \\
\hline Treatment & $26.22^{* *}$ & $414.82^{* *}$ & $316.20^{* *}$ & $0.06^{* *}$ & ${ }^{* *} 0.68$ & ${ }^{*} 359.67$ & $* * 484.4$ & ${ }^{* *} 150$ & 15 \\
\hline Error & 1.03 & 7.89 & 7.61 & 20.00 & 1.09 & 5.03 & 3.55 & 3.3 & 64 \\
\hline$(\%)$ CV & 12.39 & 6.34 & 4.29 & 6.65 & 3.3 & 9.13 & 5.23 & 5.02 & \\
\hline
\end{tabular}

** significant at $1 \%$ probability level

Table 3. Mean Comparison for effects of spent mushroom compost and vermicompost on vegetative growth Characteristic and macro elements content in aerial parts of summer savory

\begin{tabular}{|c|c|c|c|c|c|c|c|c|c|}
\hline & Treatment & $\begin{array}{l}\text { Calcium } \\
(\%)\end{array}$ & $\begin{array}{l}\text { Potassium } \\
(\%)\end{array}$ & $\begin{array}{l}\text { Phosphorus } \\
(\%)\end{array}$ & $\begin{array}{c}\text { Nitrogen } \\
(\%)\end{array}$ & $\begin{array}{l}\text { dry weight } \\
\text { (g/stand) }\end{array}$ & $\begin{array}{l}\text { Leaf area } \\
\left(\mathrm{cm}^{2} / \text { pot }\right)\end{array}$ & $\begin{array}{l}\text { Plant dry } \\
\text { weight } \\
\text { (g/stand) }\end{array}$ & $\begin{array}{l}\text { Greening index } \\
\text { of leaf (spad) }\end{array}$ \\
\hline & (control) & $1.02^{\mathrm{cd}}$ & $0.87^{9}$ & $0.47^{9}$ & $2.15^{f *}$ & $4.23^{i}$ & $25.62^{\mathrm{h}}$ & $6.65^{i}$ & $29.86^{f}$ \\
\hline 10 & \multirow{5}{*}{ 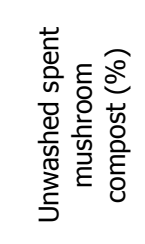 } & $0.9^{d}$ & $2.1^{f}$ & $0.81^{c d}$ & $2.5^{\mathrm{ef}}$ & $5.86^{\mathrm{fg}}$ & $28.42^{9}$ & $8.25^{\mathrm{fg}}$ & 30.76 ef \\
\hline 20 & & $1.2^{\mathrm{bcd}}$ & $2.05^{f}$ & $0.89^{\mathrm{bc}}$ & $2.55^{\mathrm{ef}}$ & $5.86^{\mathrm{hi}}$ & $28.9^{\mathrm{fg}}$ & $7.42^{h}$ & $33^{\text {de }}$ \\
\hline 30 & & $1.38^{\mathrm{bc}}$ & $3.06^{\mathrm{ab}}$ & $0.86^{\mathrm{bc}}$ & $3.75^{c d}$ & $4.67^{\mathrm{hi}}$ & $30.78^{\text {de }}$ & $7.95^{\mathrm{gh}}$ & 32.72 de \\
\hline 40 & & $2.42^{\mathrm{a}}$ & $3.00^{\mathrm{b}}$ & $0.82^{\mathrm{bcd}}$ & $3^{\text {de }}$ & $7.0^{d}$ & $31.98^{\mathrm{cd}}$ & $9.55^{d}$ & $33.24^{d}$ \\
\hline 50 & & $2.4^{\mathrm{a}}$ & $2.53^{c d}$ & $0.76^{\mathrm{de}}$ & $2.65^{\mathrm{ef}}$ & $6^{f}$ & 30.02 ef & $8.81^{\text {ef }}$ & $36.54^{c}$ \\
\hline 10 & \multirow{5}{*}{ 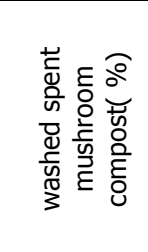 } & $1.01^{\text {cd }}$ & $2.7^{c}$ & $0.72^{\mathrm{e}}$ & $3.85^{c}$ & $7.8^{c}$ & $31.34^{\text {cde }}$ & $10.85^{c}$ & $36.36^{c}$ \\
\hline 20 & & $1.03^{\mathrm{cd}}$ & $2.3^{e}$ & $0.84^{\mathrm{bcd}}$ & $3.45^{\mathrm{cd}}$ & $5.17^{\mathrm{gh}}$ & $31.6^{\mathrm{cd}}$ & $7.64^{h}$ & $41.76^{b}$ \\
\hline 30 & & $1.37^{\mathrm{bc}}$ & $2.34^{\mathrm{e}}$ & $0.54^{\mathrm{fg}}$ & $3.45^{\mathrm{cd}}$ & $7.93^{c}$ & $30.96^{\text {de }}$ & $11.33^{b c}$ & $42.55^{b}$ \\
\hline 40 & & $1.32 \mathrm{bc}$ & $2.38^{\mathrm{de}}$ & $0.88^{\mathrm{bc}}$ & $5.25^{b}$ & $8.35^{b c}$ & $35.14^{b}$ & 11.34 bc & $33.16^{d}$ \\
\hline 50 & & $2.48^{\mathrm{a}}$ & $2.66^{c}$ & $0.82^{\mathrm{bcd}}$ & $6.1^{\mathrm{ab}}$ & $9.6^{j}$ & $30.2^{\text {ef }}$ & $5.09^{j}$ & 32.54 de \\
\hline 10 & \multirow{4}{*}{ 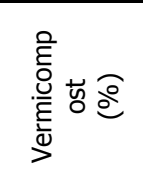 } & $1.51^{\mathrm{b}}$ & $2.61^{c}$ & $0.59^{f}$ & $3.3^{\text {cde }}$ & $9.7^{a}$ & $34.06^{b}$ & $13.31^{\mathrm{a}}$ & $54.78^{a}$ \\
\hline 20 & & $1.55^{\mathrm{b}}$ & $2.08^{f}$ & $0.9^{a b}$ & $5.9^{\mathrm{ab}}$ & $6.81^{\text {de }}$ & $38.36^{a}$ & $9.96^{d}$ & $34.14^{d}$ \\
\hline 30 & & $2.11^{\mathrm{a}}$ & $3.19^{\mathrm{a}}$ & $0.91^{\mathrm{ab}}$ & $6^{\mathrm{ab}}$ & $6.7^{j}$ & $27.92^{g}$ & $4.55^{j}$ & $38.1^{b}$ \\
\hline 40 & & $2.38^{a}$ & $2.60^{c}$ & $0.98^{\mathrm{a}}$ & $6.2^{\mathrm{a}}$ & $8.7^{b}$ & $38.04^{a}$ & $11.86^{b}$ & $41.96^{b}$ \\
\hline
\end{tabular}


Table 4. Analysis of variance of the effects of different level of vermicompost and spent mushroom compost essential oil percentage and essential oil components of summer savory

\begin{tabular}{|c|c|c|c|c|c|c|c|c|c|c|c|}
\hline \multirow[t]{2}{*}{ S.O.V } & & \multicolumn{10}{|c|}{ Means of squares } \\
\hline & & $\begin{array}{c}\text { P- } \\
\text { Cymene }\end{array}$ & $\begin{array}{c}\text { Alpha- } \\
\text { Terpinene }\end{array}$ & $\begin{array}{l}\text { Delta- } \\
\text { 3- }\end{array}$ & $\begin{array}{c}\text { Alpha } \\
\text { Phellandrene }\end{array}$ & $\begin{array}{l}\text { Alpha- } \\
\text { Thujene }\end{array}$ & $\begin{array}{l}\text { Myrc } \\
\text { ene }\end{array}$ & Terpino & $\begin{array}{l}\text { Gamma- } \\
\text { Terpinene }\end{array}$ & $\begin{array}{c}\text { Carvacr } \\
\text { ol }\end{array}$ & $\begin{array}{l}\text { essential } \\
\text { oils }\end{array}$ \\
\hline Treatment & 15 & $1.55^{*}$ & $0.033^{* *}$ & $\begin{array}{c}\text { Carene } \\
0.66^{*}\end{array}$ & $0.04 * *$ & $0.024 * *$ & $0.53 *$ & $30.73^{* *}$ & $26.43 *$ & $0.55^{* *}$ & $0.085^{* *}$ \\
\hline Error & 64 & 0.287 & 0.11 & 0.005 & 0.005 & 0.011 & 0.67 & 18.16 & 14.94 & 0.318 & 0.001 \\
\hline $\mathrm{CV}$ & & 20.10 & 15.68 & 26.2 & 22.5 & 14.75 & 21.77 & 6.66 & 14.83 & 28.46 & 1.57 \\
\hline
\end{tabular}

** is significant difference at $1 \%$ probability level

(Table 3). The maximum nitrogen (6.2\%) and phosphorus $(0.98 \%)$ content was observed in $40 \%$ vermicompost treatment. There was no significant difference between 20,30 and $40 \%$ vermicompost treatments. The maximum potassium content $(3.19 \%)$ was also obtained from $30 \%$ vermicompost treatment. There was no significant difference between 30\% vermicompost and 30\% unwashed SMC (3.06\%) treatments in terms of potassium content. The maximum calcium content was related to 30,40 and $50 \%$ vermicompost treatments and $50 \%$ washed SMC as well as 40 and $50 \%$ unwashed SMC treatments. The minimum nitrogen, phosphorus and potassium (2.15, 0.47 and $0.87 \%$ ) were observed in control treatment, whereas the minimum calcium content $(0.9 \%)$ was related to $10 \%$ unwashed SMC treatment (Table 3).

According to the results vermicompost application could increase nitrogen content in plant tissues compared with control treatment and other treatments. This might be due to these facts that vermicompost not only provides more nitrogen in the form of nitrate (Joshi et al., 2015) it increases soil cation exchange capacity and soil buffering properties (Theunissen et al., 2010). Increase in nitrogen uptake due to $20 \%$ vermicompost application in summer savory (Naiji and Souri, 2015) and dragonhead (Abbaszadeh and Zakerian, 2016) has been previously reported. (Darzi and Haj Seyed Hadi, 2016) reported that the maximum nitrogen content was related to 10 ton ha-1 vermicompost + biological fertilizers compared with cattle manure, biological fertilizer and combination of them (Darzi and Haj Seyed Hadi, 2016). (Ahmad Abadi et al., 2011) have also found that application of vermicompost for three consecutive years could increase iron and zinc content in borage leaves and flowers (Ahmad Abadi et al., 2011). Our results are in agreement with these findings. The results indicate that

Table 5. Mean comparison the effects of different level of spent mushroom compost and vermicompost on essential oils component of summer savory

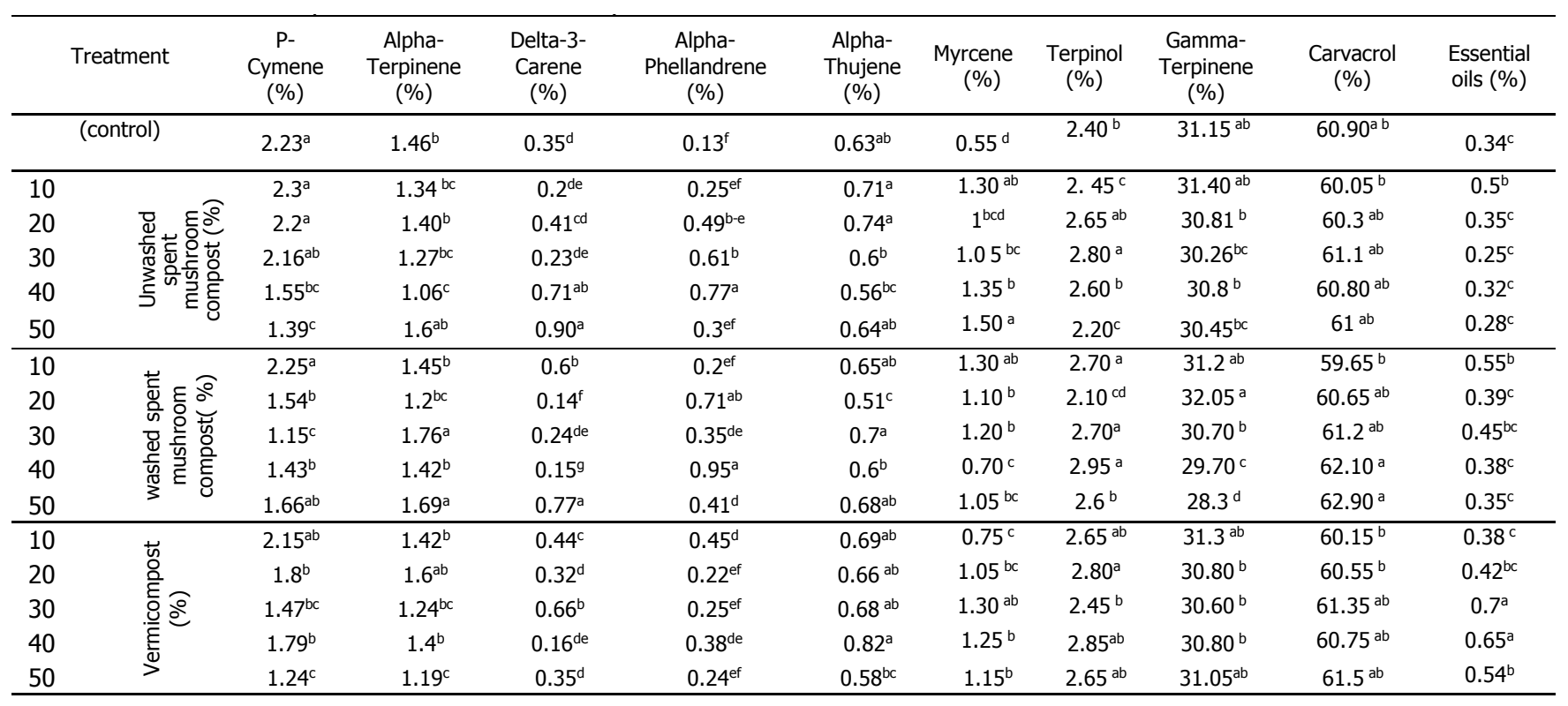


washed and unwashed SMC could increase nutrients uptake compared with control treatment. However, the effect of vermicompost was more pronounced in comparison with SMC. The application of SMC increases calcium, magnesium, sulfate and potassium availability, hence provides better conditions for plant growth and development (Mir Soheyl and Gholami, 2008; Ratti et al., 2001). In a study, the effect of vermicompost and SMC was found to be significant on plant height, chlorophyll content, leaf area and macro nutrients content in mint plants (Kiani et al., 2014). Increase in nitrogen and potassium content in pepper leaves (Kubilay Onal and Topcuoglu, 2007) increase in soil phosphorus content (Medina et al., 2012) and increase in leaves phosphorus content in some ornamental trees (Chong, et al., 1991) have been previously reported.

\section{Essence Composition}

The results showed that the effect of vermicompost and SMC application was significant on essential oil percentage, carvacrol, terpineol, alpha- thujene, alpha phellandrene, alpha-terpinene, gamma-terpinene, myrcene, delta-3-caren and p-cymene (Table 4). In addition, the comparison of means showed that there is a significant difference between fertilizers treatments in terms of essence content and composition (Table 5). The maximum essential oil percentage was found in 30 and $40 \%$ vermicompost treatment, whereas the minimum essence percentage was related to $30 \%$ washed SMC treatment. There results showed that carvacrol, gamma-terpinene, terpineol and myrcene were the most abundant compounds of essential oil. The maximum carvacrol content was obtained when 40 (62.10) and $50 \%$ (62.90) washed SMC was applied. The minimum carvacrol content (59.65) was observed in $10 \%$ washed
SMC treatment. The maximum (32.05) and minimum (28.3) gamma-terpinene content were related to $20 \%$ washed SMC and $50 \%$ washed SMC, respectively. The maximum myrcene (1.50) was found from $50 \%$ unwashed SMC treatment. The maximum Terpineol was achieved from 30\% unwashed SMC (2.80), 20 (2.80) and $40 \%$ (2.85) vermicompost treatments. However, there was no significant difference between these treatments and 10 and $30 \%$ washed SMC treatments.

The maximum alpha- thujene content was related to $10(0.71)$ and $20 \%(0.74)$ washed SMC and $40 \%$ (0.72) vermicompost. Among essence compounds, the maximum alpha phellandrene (0.95) was obtained from $40 \%$ washed SMC treatment. Although there was no signifncat difference between this treatment and 30\% unwashed SMC treatment and 20 and $40 \%$ washed SMC treatments. The minimum content was observed in control treatment. The maximum delta-3-caren content (0.97) was found in 50\% washed SMC treatment. Moreover, the maximum alpha-terpinene (1.6) was related to $20 \%$ washed SMC treatment. In case of p-cymene the maximum content (3.15) was obtained when $30 \%$ washed SMC was applied, thirteen times higher than in $50 \%$ vermicompost treatment (0.24) and $47 \%$ higher than control treatment (2.15).

Since essences are terpenoids compounds and their biosynthesis needs a lot of ATP and $\mathrm{NADPH}$, a considering the role of $\mathrm{N}$ and $\mathrm{P}$ in their biosynthesis (Loomis and Corteau, 1972), application of vermicompost could increase essence content through increasing $\mathrm{N}$ and $\mathrm{P}$ availability (Sefidkon et al., 2005). Nitrogen play a critical role in chlorophyll and carbon metabolism enzymes biosynthesis so that nitrogen application improves photosynthesis efficiency in plants. Plants produce more leaves when nitrogen

Table 6- Coefficient correlation of vegetative growth Characteristic and macro elements content in aerial parts of summer savory

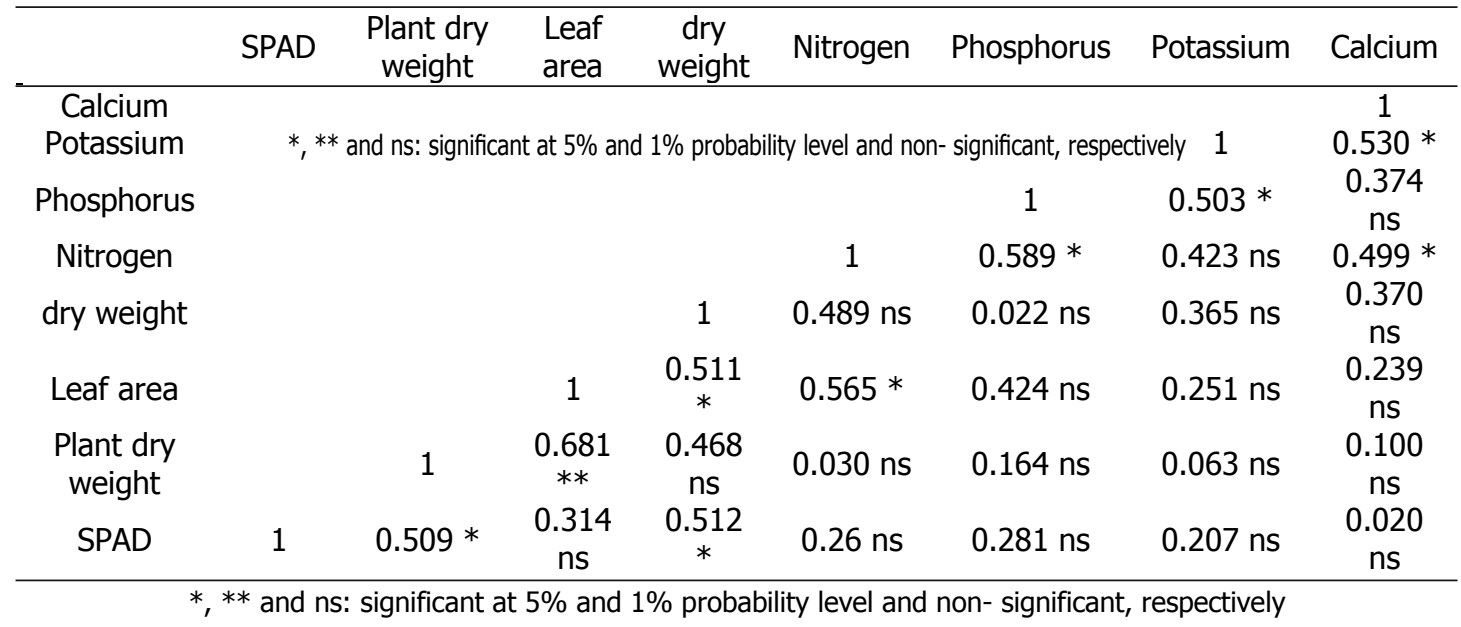


is sufficient in their growth media. All these factors cause increased photosynthesis efficiency and essence biosynthesis in plants. Therefore, organic fertilizers such as vermicompost increase essence production in plants through increasing nitrogen availability (Nooshkam et al., 2015). In a study (Rezvani-Moghadam et al., 2013) have stated that application of organic fertilizers increases essence content in summer savory plants (Rezvani-Moghadam et al., 2013). Similarly, (Makizadeh Tafti et al., 2012) have reported that chemical and biological fertilizers, containing plant growth promoting bacteria could increase growth parameters and essence content in summer savory plants (Makizadeh Tafti et al., 2012) so that the maximum essence was obtained from integrated treatment. In another study on (Satureja sahandica) the maximum alpha-terpinene and gammaterpinene were reported when 2 ton $\mathrm{h}^{-1}$ vermicompost and 40 liter vermi $\mathrm{T}$ was applied, in addition, the maximum carvacrol was obtained when 4 ton vermicompost was used (Hossaini et al., 2015). (Anwar et al., 2005) studied the effect of organic fertilizers on basil and reported that the application of 5 and 10 ton ha-1 vermicompost could increase essence content through improving soil physical and biological properties (Anwar et al., 2005). (Darzi and Seyed Hadi, 2015) have stated that application of 10 ton ha-1 vermicompost increases essence percentage and yield in dragonhead (13). Increase in essence content and yield in mint (Kiani et al., 2014), dragonhead (Darzi et al., 2015; Mafakheri et al., 2012) and Dracocephalum Neamati et al., 2014) have been previously reported. The current results are in garment with previous findings.

\section{CONCLUSION}

In general, the results indicated that application of organic fertilizers could increase growth parameters, essence yield and nutrients uptake in summer savory compared with control treatment. It appears that vermicompost and SMC application, in comparison with control treatment, provide better condition for beneficial microorganisms living in the soil. Among the treatments, vermicompost caused the maximum yield compared with other treatment. In addition, washed SMC showed better effect on studied traits compared with unwashed SMC, which might be due to higher salinity in unwashed SMC.

\section{REFERENCES}

Abbaszadeh, B., and Zakerian, F. )2016(. Elements uptake in Balm (Melissa officinalis L.) under the effect of mycorrhiza and Piriformospora indica and vermicompost. Iran. J.Medici Arom Plants. 32: 47-59. (In Persian)
Adinarayana, V., and Kumar, S.T. )2006(. Effect of applied phosphorus and vermicompost on removal of heavy metals by leafy vegetables in polluted soil. 18th World Congress of Soil science, Philadelphia, Pennsylvania, USA.

Ahmadabadi, Z., Ghajarsepanlo, M., and Bahmanyar, A. )2011(. Effect of vermicompost application on amount of microelements in soil and in the medicinal plants of Borage (Borago officinalis). J. Crop Improv. 13: 1-12. (In Persian)

Anwar, M., Patra, D.D., Chand, S. and Khanuja, S.P.S. (2005(. Effect of organic manures and inorganic fertilizer on growth, herb and oil yield, nutrient accumulation, and oil quality of French Basil. Commun Soi Sci Plan Anal. 36: 1737-1746.

Arancon, N., Edwards, C., Yardim, E., Oliver, T., Byrne, R., and Keeney, G. (2007). Suppression of two-spotted Spider Mite (Tetranychus urticae), Mealybug (Pseudococcus sp.) and Aphid (Myzus persicae) populations and damage by Vermicomposts. Crop Prot. 26: 29-39.

Arthur, E., Cornelis, W., and Razzaghi, F. (2012). Compost Amendment to sandy soil affects soil properties and greenhouse Tomato productivity. Compost Sci Util. 20: 215-221.

Asghari, M., Habibi, D., and Brogerdi, G.N. (2012). Effect of Vermicompost, Plant Growth Promoting Rhizobacteria and Humic Acid on Growth Mentha piperita L., in Central Province. Iran J Agron Plant Breed. 7: 41 - 54. (In Persian)

Atiyeh, R. M., Arancon, N., Edwards, C. A., and Metzger, J. D. (2000). Influence of earthworm processed pig manure on the growth and yield of greenhouse Tomatoes. Bioresour Technol. 75: 175-180.

Bachman, G. R., and Metzger, J. D. (2007). Growth of bedding plants in commercial potting substrate amended with vermicompost. Bioresour Technol. 99: 3155-3161.

Betnal, M. P., Navarro, A. F., Sanchez-Monedero, M. A., Roig, A., and Cegarra, J. (1998). Influence of sewage sludge compost stability and maturity on carbon and nitrogen mineralization in soil. Soil Biol Biochem. 30: 305-313.

Chong, C., Cline, R., Rinker, D., and Allen, O. (1991). Growth and mineral nutrient status of containerized woody species in media amended with Spent Mushroom Compost. J Am Soc Hortic Sci. 116: 242-247.

Courtney, R., and Mullen, G. (2008). Soil quality and Barley growth as influenced by the land application of two compost types. Bioresou Technol. 99: 2918-2913.

Darzi, M. T., and Haj Seyed Hadi, M. R. (2015). The Role of Separated and Integrated Application of Organic and Biological Inputs on N, P, K Concentration, Essential Oil of Dragonhead (Dracocephalum moldavica L.). J Sustain Agri Prod Sci. 26: 101-113. (In Persian) 
Emami, A., Shams Ardakani, M. R., and Mehregan, I. (2004). Encyclopedia of Medicinal Plants. Traditional Medicine \& Materia Medica Research Center (TMRC), Shaheed Beheshti University of Medical Sciences. PP: 449. (In Persian)

Frankenberger, W. T., and Mohammad Arshad, J. R. (1995). Phytohormones in Soils: Microbial Production and Function. Marcel and Decker, New York. Pp: 503.

Gholami Sharafkhane, E., Jahan, M., Banayan Avval, M., Koocheki, A., and Rezvani Moghaddam, P. (2015). The effect of organic, biological and chemical fertilizers on yield, essential oil percentage and some agroecological characteristics of summer savory (Satureja hortensis L.) under Mashhad conditions. J Agroeco. 7: 179-189. (In Persian)

Gonani, Z., Riahy, H., and Sharifi, K. (2011). Impact of using leached spent mushroom compost as a partial growing media for horticultural plants. J Plant Nutr. 34: 337-344.

Hadian, J., Tabatabaei, S M F., Naghavi, M R., Jamzad, Z. and Ramak-Masoumi, T. (2008). Genetic diversity of Iranian accessions of Satureja hortensis L. based on horticultural traits and RAPD markers. Sci Horti. 115: 196-202.

Hidalgo, P., Sindoni, M., Matta, F., and Nagel, D. H. (2002). Earthworm Castings Increase Germination Rate and Seedling Development of Cucumber. Mississippi Agricultural and Forestry Experiment Station.

Hossaini, S.M., Aghaalikhani, M., Sefidkon, F., and Ghalavand A. (2015). Vegetative and essential oil yields of savory (Satureja sahendica Bornm.) affected by vermicompost and Redroot Pigweed (Amaranthus retroflexux L.) competition. Iran J Medicin Arom Plants. 31: 342 - 356. (In Persian)

Joshi, R., Singh, J., and Vig, A.P. (2015). Vermicompost as an effective organic fertilizer and biocontrol agent: effect on growth, yield and quality of plants. Rev. Environ Sci Biotech. 14: 137-159.

Kiani, Z., Esmaeilpour, B., Hadian, J., Soltani Toolarood, A.A., and Fathololumi, S. (2014). Effect of organic fertilizers on growth properties nutrient absorption and essential oil yield of medicinal plant of spearmint (Mentha spicata L.). J Plan Prod. 21: 63-80. (In Persian)

Kubilay Onal, M., and Topcuoglu, B. (2007). The effect of spent mushroom compost on the dry matter mineral content of pepper (Piper Nigrum) grown in greenhouse. Akdeniz University Vocational High School of Technical Sciences. Turkey. Tropentag. 9-11.

Locanzo, C., Arnold, J., Tato, A., Zaller, J. G., and Dominguez J. (2009). Compost and vermicompost a nursury pot component: effect on tomato plant growth and morphology. Span J Agric Res. 7: 944-951.

Loomis, W. D., and Corteau, R. (1972). Essential oil biosynthesis. Recently Advance Phytochem. 6: 147-185.
Mafakheri, S., Omidbaigi, R., Sefidkon, F., and Rejali, F. (2012). Effect of vermicompost, biophosphate and Azotobacter on quantity and quality of essential oil of (Dracocephalum moldavica L.) Iran J Medici Arom Plants. 27: 599-605. (In Persian)

Makkizadeh Tafti, M., Chaichi, M., Nasrollahzadeh, S., and Khavazi, K. (2012). Effect of different types of nitrogen fertilizers on quantitative and qualitative characteristics of Satureja hortensis L. Iran J Medici Arom Plants. Plants. 28: 330-341. (In Persian)

Mcginnis, M., Cooke, A., Bilderback, T., and Lorscheider, M. (2003). Organic fertilizers for basil transplant meadow bromegrass. Crop Sci. 30: 967-970.

Medina, E., Paredets, C., Bustamante, M.A., Moral, R., and Moreno-Caselles, J. (2012). Relationships between soil physico-chemical and biological properties in a soil amended with Spent Mushroom Substrate. Geoder. 173: 152-161.

Mir Soheyl, M. and Gholami M R. (2008). Vermicompost and its production. J Olive. 186:43-44.

Muscolo, A., Bovalo, F., Gionfriddo, F., and Nardi, F. (1999). Earthworm humic matter produces auxin-like effects on Daucus carota cell growth and nitrate metabolism. Soil Biol Biochem. 31: 1303-1311.

Naiji, M., and Souri, M.K. (2015). Evaluation of growth and yield of Savory (Satureja hortensis) under organic and biological fertilizers toward organic production. Plant Prod. 38:3. 93-103.

Neamati, H., Azizi, M., Mohammadi, S., and Karimpour, S. (2014). The study on the effect of spraying with different concentrations of vermicompost extract (vermiwash) on the morphological traits, yield and percentage of essential oil of lemon balm (Melissa officinalis L.). J.Horti Sci. 27: 411-417. (In Persian)

Nooshkam, A., Majnoun Hosseini, N., Hadian, J., and Jahansooz, M. R. (2015). Study the effects of biological and chemical fertilizers on quantitative and qualitative characteristics of Savory species (Satureja khuzestanica Jamzad). J.Crop Prod. 8: 87-103. (In Persian)

Omidbeigi, R. (2000). Approaches to Production and Processing of Medicinal plants, vol. (3). Beh Nashr Publisher, Mashhad. (In Persian).

Omidbaigi, R., Hejazi, M. (2004). Essential oil content and composition of Satureja hortensis of two different origins. J. Ess Oil Bear Plants. 7: 175-178.

Peregrina, F., Larrieta, C.,Martin, I., Martinez-Vidaurre, J.M., and Garcia -Escudero, E. (2009). Effect of application spent mushroom compost as organic amendment in vineyard soil of the origin denomination rioja (Spain). Geophysical Res Ab. 11: 368-5.

Philippoussis, A., Zervakis, G.I., Diamantpoulou, P., Papadopoulou, K., and Ehaliotis, C. (2004). Use of spent 
mushroom compost as a substrate for plant growth and against plant infections caused by Phytophthora. Mushroom Sci. 16: 579-584.

Pradha, M.L., Jayraaj, I.A., Jayraaj, R., and Rao, D.S. (2007). Effect of vermicompost on growth parameters of selected vegetable and medicinal plants. Asian J Microbiol Biotech Environ Sci. 9: 321-326.

Ratti, N., Kumar, S., Verma, H.N., and Gautam, S.P. (2001). Improvement in bioavailability of tricalcium phosphate to (Cymbopogon martinii var.) motia by Rhizobacteria, AMF and Azospirillum inoculation. Microbiol. Res 156: 145-149.

Rezaee Moadab, A., and Nabavi Klat, S. M. (2012). The Effect of Vermicompost and Biological Fertilizer Application on Seed Yield and Yield Components of Basil (Ocimum basilicum L.). J.Crop Ecophysio 6: 157-170. (In Persian)

Rezaeifar, P., and Alizadeh Oskuie, P. (2015). Effects of Vermicompost and Magnetic Water on growth of Ocimum basilicum. Advan..Biores 6: 99-103.

Rezvani Moghaddam, P., Aminghafori, A., Bakhshes, S., Jafari, L. (2013). The effect of organic and biofertilizers on some quantitative characteristics and essential oil content of Summer Savory (Satureja hortensis L.). Agroeco 5: 105112. (In Persian).

Sangwan, P., Kaushik, C.P. and Garg, V.K. (2008). Vermiconversion of industrial sludge for recycling the nutrients. Bioresour Technol 99: 8699-8704
Sefidkon, F., Jamzad, Z., and Barazandeh, M. (2005). Essential oil of (Satureja bachtiarica) Bunge, A potential source of Carvacrol. Iran J Medici Arom Plants 20: 425 - 39.

Sharma, A. K. (2002). Biofertilizers for Sustainable Agriculture, A handbook of Organic Farming. Agrobios, India, 300p.

Singh, U.P., Maurya, S., and Singh, D.P. (2003). Antifungal activity and induced resistance in pea by aqueous extract of vermicompost and for control of Powdery Mildew of Pea and Balsam. J. Plant Dis Protect 110: 544-553.

Theunissen, J., Ndakidemi, P. A., and Laubscher, C. P. (2010). Potential of vermicompost produced from plant waste on the growth and nutrient status in vegetable production. International Journal of the Physical Sciences. 5: 19641973.

Tiwari, S.C., B.K. Tiwari, and R.R. Mishra. (1989). Microbial populations, enzymes activities and nitrogenphosphorus-potassium enrichment in earthworm casts and in surrounding soil of a Pineapple plantation. Biol Fertil Soils 8:178-182.

Yousefi, S. M., Chalavi, V., and Zangi, S. (2015). The effect of different levels of vermicompost and photoperiod on greenhouse production of medicinal plant Stevia (Stevia rebaudiana Bertoni). J Sci Technol Green Cult 6: 31-39 